ISSN: 0213-2052 - eISSN: 2530-4100

DOI: https://doi.org/10.14201/shha202139135162

\title{
LA RELIGIÓN COMO INSTRUMENTO DE MANIPULACIÓN POLÍTICO-MILITAR EN ROMA DURANTE LA SEGUNDA GUERRA PÚNICA*
}

\section{Religion as an Instrument of Political-Military Manipulation in Rome during the Second Punic War}

\author{
Carlos DÍAZ SÁNCHEZ \\ Universidad Complutense de Madrid \\ cardia01@ucm.es
}

Fecha de recepción: 6-5-2020 Fecha de aceptación: 8-2-2021

ORCID: https://orcid.org/0000-0001-5706-8733

RESUMEN: La religión ha sido utilizada reiteradamente como instrumento de manipulación política a lo largo de la historia. Durante la Segunda Guerra Púnica se pueden resaltar un gran número de hechos, tales como sanciones en los tratados o en los prodigia, que sirvieron para legitimar una causa o promocionar a diversos personajes. La instrumentalización de la religión realizada por los Bárquida durante la guerra fue neutralizada a través de un rico entramado propagandístico-ideológico romano que influyó en muchas de las actitudes de la sociedad tiberina cuya observación nos permite analizar cómo se produjo dicha manipulación romana en este periodo.

* Esta investigación se ha desarrollado en el marco de un contrato predoctoral de personal investigador en formación cofinanciado entre la Universidad Complutense de Madrid y el Banco Santander (CT 63/19-64/19). 
Palabras clave: ideología; prodigios; manipulación religiosa; instituciones sacras.

ABSTRACT: Religion has been repeatedly used through History as an instrument for political manipulation. During the 2nd Punic War, numerous events served to legitimize a cause or to promote a series of prominent personalities, such as sanctions on treaties or prodigia. The instrumentalization of religion by the Barcine during the war was neutralized through a rich ideological Roman propaganda that deeply influenced the opinions and behaviours within the tiberian society. Its analysis allow us to understand the origins and the management of this manipulation during the conflict.

Keywords: ideology; wonders; religious manipulation; sacred institutions.

\section{INTRODUCCIÓN}

La religión ha servido como impulso, motivo o influencia en las decisiones político-sociales del mundo antiguo. Las primeras sociedades históricas, en palabras de Plácido $^{1}$, eran eminentemente religiosas, puesto que tomaban muchas de las resoluciones más importantes de la sociedad o comunidad a través de "consultas" con la divinidad regente. La aceptación de esta premisa es unánime, ya que ninguna de las civilizaciones que imperaron en la antigüedad se desligó completamente de sus ritos y sacralizaciones básicas. El mundo romano no fue una excepción: muchas de las decisiones políticas, militares, sociales o, incluso, familiares estaban muy marcadas por los auspicios divinos. En algunas situaciones de extremo peligro, la sociedad romana creía que divinidades les enviaban señales para advertir que se iban a producir diferentes desastres o calamidades $^{2}$ y, con el fin de solventarlas, estos podrían buscar soluciones en diversos ritos religiosos y en el apoyo de las divinidades. Este tipo de actitudes podrían ser aprovechadas por algunas élites para, a través del falseamiento de los augurios o de sus creencias, sacar algún tipo de rédito político, militar o social ${ }^{3}$. La Segunda Guerra Púnica fue uno de los momentos de mayor crisis durante la República, por lo que tanto las

1. Plácido 2008, 289.

2. Existen un gran número de publicaciones que tratan los prodigios religiosos y cómo la sociedad romana creía que la divinidad se comunicaba con ellos a través de su manifestación Vid. entre otros: Bloch 1968, 155; Montero 1994, 77 y ss.; Domínguez Pérez 2002, 303; Cid López 2007, 13.

3. Domínguez Pérez 2002, 209-301. 
fuentes como la investigación han prestado atención al incremento de advertencias religiosas, manipulaciones en los auspicios y prodigios capaces de aplacar la ira de los dioses y neutralizar el entramado propagandístico en el campo ideológico de los cartagineses liderados por Aníbal Barca $^{4}$. En este contexto se puede observar cómo la religión se utilizó como un instrumento de adulteración político-social en función de los intereses de ciertos personajes o del Estado. No es una cuestión única de esta guerra, ya que en gran parte de la historia se trata de la tónica habitual entre la aristocracia dominante, empleando la religión como un método por el cual legitimar una causa al considerarla sagrada, divina o influenciada por una deidad.

El objeto de nuestra investigación versa sobre los diferentes mecanismos de instrumentalización religiosa que se observan en el mundo romano durante el transcurso del segundo conflicto romano-cartaginés. Este ensayo pretende llenar un vacío dentro de los estudios monográficos de la religión durante este conflicto, habitualmente centrados en la tradición púnica durante el imperialismo Bárquida y al uso que Aníbal Barca ejerció durante la guerra ${ }^{5}$, al igual que al impacto que tanto Cartago como Roma generaron en las poblaciones ibéricas ${ }^{6}$. En el caso romano, la historiografía se ha centrado principalmente en los aspectos religiosos de los diferentes prodigios 7

4. Sobre la cuestión propagandística y la instrumentalización por parte de la familia Bárquida existe una amplia bibliografía. Vid. Bloch 1975, 14-25; Breglia Pulci Doria 1983 , 77 y ss.; Chaves Tristán y Marín Ceballos 1992, 167-194; Erskine 1993, 58-62; Stepper 2006, 397-407; Fronda 2007; Miles 2011, 260 y ss.; Barceló 2001, 63-80; 2010, 74-82 y 135-148; 2012, 163-165; 2013, 164-169; Bendala Galán 2015, 149-150.

5. Cfr. Bloch 1975, 14-25; Blázquez 1979; 1983; 1986; 1990; 1994; Huss 1986, 223 238; Erskine 1993, 58-62; Smith 1986, 34-47; López Castro 1998, 93-108; Engels 2005, 157; Stepper 2006, 397-407; Hoyos 2011, 204-222; Miles 2011; González Wagner 2012, 266-272; Barceló 2001; 2004, 70 y ss.; 2010, 74-82 y 135-148; 2011, 357-375; 2012, 160-172; 2013, 164 y ss.; Brizzi 2014, 61; Bendala Galán 2008, 25 y ss.; 2013, 70 y ss.; 2015, 149-150; GarcíaBellido 2010, 201-218; 2013, 177.

6. Autores como Bendala Galán (1986), García-Gelabert (1990), González Wagner (1999), López Monteagudo y San Nicolás Pedraz (1996), Domínguez Monedero (1999), Blázquez y García-Gelabert (2000), Almagro Gorbea (1978; 2004) o García Cardiel (2013) afirman que la religión ibérica tuvo un nivel de hibridación con las religiones venidas del Mediterráneo como las fenicio-púnicas y su posterior aprovechamiento de estas por la civilización cartaginesa y romana.

7. Existen un gran número de obras que reseñan diferentes prodigios a lo largo de la historia de Roma, realizándose reflexiones en conjunto y señalando algunos de los ejemplos ocurridos durante la Segunda Guerra Púnica. (Cfr. Bloch 1968; Cornell 1981; Breglia Pulci Doria 1983; Montero 1994; Domínguez Pérez 2002; Schultz 2006; Cid López 2007). 
o en la figura de Escipión el Africano ${ }^{8}$, dejando a un lado el uso de la religión como forma de legitimación en otras figuras o como contraparte en la lucha ideológica del conflicto. Para abordar este análisis se han separado en tres los aspectos principales correspondientes a la influencia religiosa: los tratados, pactos y política externa; la política interna, y el ámbito militar, como también el aprovechamiento religioso de Roma sobre otros pueblos?

\section{La influencia Religiosa en los tratados, pactos y política externa de Roma durante la Segunda Guerra Púnica}

En el mundo romano, la guerra requirió de una aceptación y validación por las deidades que adoraban, para que así fuera considerada un conflicto justo. Este cometido recayó en los fetiales ${ }^{10}$ : un colegio de sacerdotes que sirvieron como legados, diplomáticos y mediadores de la República. El origen de este collegium está muy discutido por las diferentes versiones que se exponen en las fuentes, algunas las sitúan bajo el reinado de Numa Pompilio ${ }^{11}$, quien consagró un collegium a la guerra, mientras que en otras versiones se alude a sus sucesores como los creadores de este ${ }^{12}$. Autores actuales, como

8. Cfr. Anderson 1928, 758; Walbank 1967, 54-69; Cabrero Piquero 2000, 24-27; Campus 2008, 121-182; Quesada Sanz 2013, 175-207; 2016, 75; Breccia 2017, 16-19; Montero 2020, 114-115.

9. Como pudiera ser el caso de la utilización de las instituciones religiosas de la fides y la devotio ibéricas en su beneficio. Esta última se puede observar también en la adulteración religioso-política de los Bárquidas durante el ejercicio de su imperialismo en la Península Ibérica a través de la imitatio Alexandrii y la asimilación con el héroe y divinidad Melqart/Herakles. (Cfr. Villaronga 1973; Barceló 2001; 2004; 2011; 2013; Hoyos 2011; García-Bellido 2010; 2013; Bendala Galán 2008; 2013; 2015; San José Campos 2020, 21-48). El empleo de este mecanismo de manipulación cartaginesa fue aprovechado con el tiempo por la aristocracia romana durante la guerra (Cfr. Ramos y Loscertales 1924, 7; Étienne 1958, 77; Prieto 1978, 133; Santos Velasco 1989, 141 y ss.; Curchin 1996, 143-152; Greenland 2006, 235-237; García Cardiel 2013, 302-303; Alarcón Hernández 2013, 209-226, entre otros).

10. El estudio de los fetiales ha sido abarcado por numerosos autores entre los que destacan las obras de Walbank (1949, 15-19), Schullard (1952, 209-216), Oost (1954, 147-159), Dumézil (1956; 1966), Harris (1978, 167; 268-269), Kakarieka (1981, 16-19), Wiedemann (1986), Madrid (1992), Sgarbi (1992, 71-78), Mangas (1994, 281), Buono-Core Varas (2003, 23-24), Santangelo (2008, 63-93), Martínez-Pinna (2011, 114-115), López Barja de Quiroga (2011, 69-71), Rich (2011, 187-242), Galindo Roldán (2013, 207), Jiménez Rojas (2013), entre otros.

11. Dionisio de Halicarnaso (2. 72) y Plutarco (Numa, 12. 4-13) exponen como estos eran los guardianes de la paz, árbitros y garantes de las causas de la guerra justa.

12. Cicerón (Rep. 2. 31) expone que fue Tulo Hostilio el que creó esta institución, contraponiendo a los otros cronistas. Tito Livio $(1.32,5)$ expone que no fue Tulo Hostilio, sino su sucesor Anco Marcio quien creó dicho collegium sacerdotal. 
Riesco Álvarez ${ }^{13}$ o Rich ${ }^{14}$, dan como válida la versión de Valerio Máximo al concederle la creación de este collegium a Fertor Resio, hipótesis que defienden por el descubrimiento de una inscripción que apoya esta explicación ${ }^{15}$. Este colegio sacerdotal tuvo una importancia significativa para los conflictos y las incursiones romanas fuera de su ager. En este aspecto, los feciales fueron los encargados en declarar la guerra y asegurarse de que Roma emprendía sus conflictos cuando la causa era justa y la divinidad se lo permitía, en otras palabras, cuando los dioses aceptaban que la Vrbs emprendiera una contienda fuera de su territorio ${ }^{16}$. No obstante, la actuación de este colegio religioso en el exterior de la ciudad ha sido discutida por la investigación actual, algunos autores como Walbank ${ }^{17}$ exponen cómo las atribuciones para declarar la guerra de este colegio religioso fueron cambiando paulatinamente a favor de legados sin atribución sacerdotal durante la Segunda Guerra Púnica ${ }^{18}$; en cambio, Rich ${ }^{19}$ analiza cómo, en muchas ocasiones, las fuentes no hacen distinción entre los fetiales y los embajadores. Mientras que Santangelo ${ }^{20}$ atribuye el primordial papel de estos sacerdotes en la declaración de la guerra, aunque ve probable cómo, salvo algunas excepciones, estos realizaran su labor en el territorio romano y no en el enemigo. Otros investigadores como Widemann o Mangas describen cómo este collegium religioso se encargó de las relaciones diplomáticas con los aliados y los enemigos de la ciudad, pues se les consideraba como representantes de Roma que actuaban como heraldos o embajadores que ratificaban los tratados o declaraban la guerra a otros pueblos $^{21}$.

La sanción religiosa era innata en las funciones del colegio sacerdotal, lo que le aportaba validez para las decisiones que tomaban, puesto

13. Riesco Álvarez 1988, 20.

14. Rich 2011, 188.

15. Richardson (2017) analiza cómo el ritual realizado por este collegium que describen las fuentes puede haberse originado durante el siglo III a.C. y no con anterioridad.

16. Riesco Álvarez 1988, 20; Harris 1989, 17; Rich 2011, 187; Jiménez Rojas 2013, 52; Galindo Roldán 2013, 207.

17. Walbank 1949, 15-19.

18. Rich plantea una variación en la hipótesis de Walbank, describiendo cómo los fetiales tuvieron atribuciones en la declaración de guerra con posterioridad a la Segunda Guerra Púnica siempre que el conflicto tuviera la necesidad de una sanción divina para poder realizarlo (Rich 2011, 225-226).

19. Rich 2011,

20. Santangelo 2008, 78-80. Sobre las excepciones, Santangelo describe cómo los fetiales fueron a Cartago para pactar la rendición de esta tras la Segunda Guerra Púnica, aunque en muchas ocasiones estos no saldrían del territorio romano (Santangelo 2008, 91).

21. Widemann 1986, 479; Mangas 1994, 281-282; Rich 2011, 189. 
LA RELIGIÓN COMO INSTRUMENTO DE MANIPULACIÓN POLÍTICO-MILITAR EN ROMA..

que eran consideradas legítimas por la divinidad a la que se encomendaban ${ }^{22}$. Algunos investigadores han desarrollado cómo el papel de este collegium fue de gran importancia en la declaración de guerra contra Cartago, pues para la civilización tiberina el conflicto fue justo y no violaba la pax deorum del pueblo romano con sus dioses ${ }^{23}$. Domínguez Pérez ${ }^{24}$ considera que la función principal de los fetiales fue su desempeño como diplomáticos durante la embajada enviada por Roma al Senado de Cartago tras la destrucción de Sagunto. Los romanos consideraban que el ataque a Sagunto ${ }^{25}$ violaba la Paz de Catulo y el Tratado del Ebro, ratificados por el collegium fetiale ${ }^{26}$. En esta reunión, los romanos portaron la rerum repititio con la cual se exigía a Cartago que reconsiderase su postura para evitar el conflicto bélico ${ }^{27}$. No obstante, tras agotar la diplomacia por medio de esta fórmula, las divinidades romanas debían considerar justas las causas de la contienda, por lo que, gracias al favor de los dioses, interpretado a través de este collegium, se declaraba la guerra al validar sus premisas y considerar el carácter del conflicto como justo para los romanos. La actuación de los fetiales no se vuelve a observar hasta el final de la guerra, con la ratificación del tratado de paz que estableció Escipión para la rendición de Cartago en el 201 a. C. ${ }^{28}$. Sin embargo, existió un gran número de manipulaciones religiosas con el fin de legitimar una magistratura o de manifestar la crisis en la que Roma se vio envuelta y como forma de solventar esta situación.

\section{La inStRumentalización de la Religión en la política InTERNA De Roma durante la Segunda Guerra Púnica}

La ideología religiosa fue uno de los campos en donde se enfrentaron los cartagineses y los romanos en el transcurso de la guerra. Lejos de los conflictos armados, las luchas por el control ideológico se hicieron más

22. Kakarieka 1981, 16-19; Wiedemann 1986, 479; Rich 2011; Jiménez Rojas 2013, 47.

23. Walbank, 1949, 16; Scullard 1952, 211-214; Widemann 1986, 479; Santangelo 2008; Rich 2011, 193; Jiménez Rojas 2013, 53.

24. Domínguez Pérez 2002, 305-306.

25. La amicitia establecida años atrás con esta ciudad puede que fuera una manipulación de las fuentes para justificar la causa justa de Roma Cfr. Plb. 3. 30. 1.; 3. 76. 2; 1.97. 2; Liv. 21. 60. 3; Ap. Iber, 7.

26. Cfr. Plb. 3. 15. 5; Liv. 21. 6. 3-4.

27. Plb. 3. 20. 6-10.

28. Plb. 15. 18. En Polibio (15. 19. 7) se detalla cómo Aníbal reclama a su pueblo que recen para que las condiciones propuestas por Escipión y firmadas por los cartagineses sean ratificadas por el pueblo de Roma. 
evidentes por parte de los Bárquida, quienes desde su etapa imperialista en la Península Ibérica construyeron un entramado religioso para atraer a la población fenicia, griega e ibérica a su causa. Para ello, ligaron su linaje a la figura de Melqart/Herakles ${ }^{29}$, conocida en todo el ámbito mediterráneo bajo diferentes nombres. Aníbal Barca empleó toda la herencia propagandística e ideológica de sus antecesores para mostrarse como un elegido de la divinidad ${ }^{30}$, consagrando su causa a esta deidad y haciéndose ver como su predilecto, al igual que lo fuera Alejandro Magno. La difusión religiosa de Aníbal iba dirigida a levantar la moral de sus tropas, atraer a un gran número de pueblos hacia su causa y desmoralizar a los romanos $^{31}$.

\subsection{La instrumentalización de la religión en la elección o el desempeño de las magistraturas}

La instrumentalización religiosa de los Bárquida no pasó desapercibida por las autoridades romanas, quienes comenzaron a realizar una serie de iniciativas sacras para contrarrestar la amenaza cartaginesa en el campo ideológico ${ }^{32}$. Roma, durante el 217 a. C., reconoció el potencial de Aníbal e invistieron con el máximo poder a Fabio Máximo para intentar contrarrestar los mecanismos sacros de aquel ${ }^{33}$. Esta elección tuvo unos motivos militares ${ }^{34}$, pero también religiosos. Este magistrado era uno de los descendientes de la gens Fabia, que a su vez provenía de la figura

29. Se puede observar en la numismática. Cfr. Villaronga 1973; Lechuga 1993; Miles 2011; García-Bellido 2010, 201-2018; 2013, 174-207; Bengala Galán 2015.

30. Tito Livio $(21.21,9)$ hace mención a la consagración de la campaña militar cartaginesa a Melqart en Gadir. Esto configuró un proceso de legitimación para su campaña, haciéndose ver como una autoridad que fuera capaz de derrotar a los romanos impíos (Bloch 1975, 14-25; Knapp 1986, 103-122; Erskine 1993, 58-62; Stepper 2006, 397-407; Barceló 2010, 74-82 y 135-148; 2021, 163-165; 2013, 167).

31. Miles (2011, 262-263). Junto a esta premisa, Engels (2005, 156) describe la instrumentalización religiosa de Aníbal como una táctica de atracción y cohesión, tanto de su ejército como de otros pueblos. Opinión similar en la investigación de Fronda (2007, 83108), quien destaca la utilización de este entramado político para que los itálicos y griegos sometidos al poder de Roma vieran en Aníbal un elemento libertador que, a medida que aumentaban sus victorias, se veía como un claro desafío a la hegemonía romana.

32. Miles 2011, 260.

33. Las victorias cartaginesas en Tesino (Plb. 3. 41-67), Trebia (Plb. 3. 68-75; Liv. 21. 5; 21. 6-7 y 53) y lago Trasimeno (Plb. 3. 82-85; Liv. 21. 63. 15) habían mermado la moral de los romanos, llegando al punto de necesitar el nombramiento de un dictador (Liv. 22. 8. 5-7).

34. Sobre los motivos militares de la elección de Fabio Máximo Vid. Barceló 2000, 115-116; Mira Guardiola XXXX, 158 y ss.; Steinby 2014, 130-131 entre otros. 
mitológica de Hércules, por lo que la elección de Fabio designaba a uno de los sucesores directos del héroe al que también se había vinculado Aníbal. Las primeras acciones que Fabio realizó no fueron en el ámbito bélico, sino en el religioso, aplicando unos sacrificios para que se aplacara la cólera divina y se constituyera la pax deorum ${ }^{35}$. Igualmente, Fabio hizo que los sacerdotes consultaran los Libros Sibilinos para poder descubrir cómo contrarrestar a Aníbal, encomendándoles la renovación de los votos del pueblo de Roma a Marte, la dedicación de un templo a Venus Ery$\operatorname{cina}^{36}$, una diosa siciliana, y una fuente sagrada si lograba la victoria ${ }^{37}$. La construcción de dicho templo se terminó en el 215 a. C. en el Capitolio. Una vez ejerciendo la dictadura, Fabio Máximo hizo saber al pueblo que las derrotas no habían sido provocadas por la ineptitud de los mandos, sino por una negligencia con los dioses que se habían puesto en su contra. Las expiaciones fueron de la mano de un éxito parcial en el ámbito militar, donde Fabio Máximo no entablaba combate directamente con el general cartaginés, prefiriendo mermar sus tropas a través de la privación de los recursos y pequeñas refriegas.

Ligado al éxito de Fabio Máximo encontramos el segundo ejemplo de la manipulación religiosa en el ámbito político. En el contexto del 217 a. C. en las cercanías de Geronium tras el incidente del Ager Faler$n$ s $^{38}$, Fabio Máximo tuvo que ausentarse del mando y marchar a Roma por motivos religiosos, dejando el mando a su magister equitum Minucio Rufo $^{39}$. El general al cargo de las tropas romanas consiguió «mermar» las fuerzas de Aníbal mientras forrajeaban las tierras, promulgando en Roma la noticia de que su ejército había conseguido derrotar al cartaginés en una batalla campal. Esta noticia fue recibida en la Vrbs como un gran éxito militar y, a través del pretor Metelo, se consiguió equiparar en poderes y cargo a Minucio Rufo y Fabio Máximo ${ }^{40}$. Este hecho documentado en las fuentes tuvo una repercusión en el ámbito propagandístico religioso

35. Cfr. Plb. 3. 88. 7; Liv. 22. 9. 7-8.

36. La dedicación de un templo a Venus Ercyna tuvo un doble significado; por un lado, la utilización de Venus como antecesora de Rómulo y Remo, ya que muchos investigadores destacan como la vinculación de Rómulo con Eneas ya era ampliamente conocida en esta fecha (Gruen 1992, 22-29; Galinsky 1969, 160-163; Miles 2011, 276); por otro lado, la elección de esta divinidad al estar relacionada con la diosa púnica Astarté que, al adaptarla al panteón romano, se le dio el nombre de Venus con el fin de integrar a los partidarios de esta ciudad dentro del mito fundacional de Roma (Schilling 1954, 235-239).

37. Cfr. Liv. 22. 9. 7-11.

38. $C f r$. Liv. 22. 23.

39. Cfr. Plb. 3. 101-102.

40. Cfr. Liv. 22. 25-26. 
que resultó en la erección de una estatua de bronce a Herakles ${ }^{41}$. En este evergetismo ${ }^{42}$ ligado a las aspiraciones políticas observamos la necesidad de legitimar su cargo como un igual de Fabio Máximo o de Aníbal ante el pueblo, destacando la protección a su causa de esta divinidad. De esta manera Minucio Rufo instrumentalizó la religión como un medio para legitimar su posición, la cual había alcanzado a través de tretas políticas ${ }^{43}$.

Existe un último ejemplo conocido del empleo de las inspiraciones divinas para alcanzar una magistratura en el contexto de la Segunda Guerra Púnica. El caso de Escipión el Africano y su elección como edil durante el año 212 a. C. estuvo muy influenciada tanto por su carisma como por su vinculación con los dioses ${ }^{44}$. Este dedicó gran parte de su tiempo a recorrer los templos de Roma y a reflexionar en ellos, mostrando cómo sus decisiones estaban dirigidas por la voluntad de las divinidades ${ }^{45}$. En opinión de Walbank ${ }^{46}$, la creencia de este favor divino hacia Escipión se potenció en las fuentes literarias tras el episodio militar de la toma de Qart Hadasht y la "supuesta intervención de Neptuno" para lograrlo. Asimismo, diversos investigadores han hipotetizado sobre cómo las fuentes literarias intensificaron la leyenda que atribuía el linaje de Escipión como si de un nuevo Hércules se tratara, al modo de un nuevo Alejandro Magno, llegando a explicar una relación filial entre Escipión y Júpiter a modo de Alejandro y Amón ${ }^{47}$. Siguiendo estos argumentos, Campus ${ }^{48}$ vincula una relación narrativa entre los casos de instrumentalización religiosa de Aníbal y de Escipión. Para dicho autor, las semejanzas descritas en las fuentes literarias entre ambos personajes sirvieron como forma de contraposición religiosa de los romanos, pues aporta diferentes ejemplos en donde el simbolismo que se empleó con ambas figuras es el mismo.

41. Dicho epígrafe fue encontrado en la Vía Tiburtina en Roma, catalogado por el Corpus Inscriptionum Latinorum y en l'Année Épigraphique CIL I ${ }^{2} 607 / /$ CIL VI $284=\mathrm{AE}$ 1991, 211 a. con la inscripción "Hercolei / sacrum / M(arcus) Minuci(us) C(ai)f(ilius) / 3 dictator vovit.

42. Acerca del evergetismo y sus motivaciones destacan las obras de Cicerón (De Officiis 1. 20. 42-49; 2. 55-64; 3. 24), Valerio Máximo (8. 1-5) o Séneca (Ep. 66. 13; 115. 3). Sin embargo, la investigación actual ha realizado diferentes estudios sobre la actitud evergetista y los motivos que la llevan a cabo. (Cfr. Rodríguez Neila 1989, 139 y ss.; Melchor Gil 1999; Andreu Pintado 2001).

43. Sobre esta cuestión Véase recientemente Díaz Sánchez 2020, 105-110.

44. Polibio (10. 4. 3-5) describe cómo Escipión «Supo explotar hábilmente la oportunidad que le ofrecieron el pueblo y su misma madre, y no sólo vio coronados sus planes por el éxito, sino que además pareció que actuaba por una inspiración divina».

45. Barceló 2013, 171.

46. Walbank 1967, 54-69.

47. Vid. Anderson 1928, 32-35; Aymard 1953, 111-116.

48. Campus 2008, 154-182. 


\subsection{Prodigios y consultas religiosas durante la guerra}

En los momentos de conflicto y crisis de la ciudad, la civilización romana pensaba que la pax deorum había sido desequilibrada y, para evitar que la cólera divina recayera sobre ellos, debían consultar a las diversas instituciones oraculares para que proporcionaran los consejos necesarios con el fin de solventar las diversas negligencias religiosas ${ }^{49}$. La disconformidad, o la aceptación de la deidad, se recreaba a través de una serie de actuaciones denominadas prodigios. Montero explica cómo, en la tradición latina, la aparición de estos prodigia siempre tenía un sentido desfavorable y anunciaba la inminencia de un peligro para la comunidad $^{50}$. La clasificación de las diferentes manifestaciones de los prodigia se hace complicada, pues, en determinadas ocasiones, aparecen mencionados con otros nombres; no obstante, era común que aparecieran ligados al cielo, a la tierra, al agua, al ser humano, a los animales o a los objetos inanimados. Un ejemplo de este tipo de características podría ser la aparición de los monstra ${ }^{51}$, que se revelaban a través de las malformaciones de los seres vivos, especialmente de los humanos ${ }^{52}$. El sacerdocio femenino, por su parte, también podía reflejar un prodigio, dado que su estabilidad repercutía directamente en la pax deorum ${ }^{53}$. Cicerón ${ }^{54}$ describe otro de los prodigia que habitualmente aparecían en momentos de crisis, los nacimientos de niños andróginos, categorizándolos como una manifestación funesta cuyo alumbramiento suponía la ruptura del equilibrio religioso con la divinidad. La aparición de terremotos, inundaciones, sequías o el movimiento de objetos inanimados fueron considerados como prodigia por la sociedad romana. Este tipo de manifestaciones funcionaban como explicación de eventos inexplicables y amenazas, a la vez que servía para la justificación de eventos realizados por alguna personalidad. De igual modo, en caso de ser resultado negativo de una acción o malestar con sus divinidades, la expiación de estos tenía como fin la regularización de

49. Las diversas instituciones que podían poner remedio ante este tipo de situaciones eran, comúnmente, el Senado, diferentes collegia religiosos, decenviros, la consulta de los Libros Sibilinos y los arúspices, estos últimos de tradición etrusca (Montero 2020, 12).

50. Montero 2020, 9. Diferente situación era para otras culturas, donde podían tener connotaciones favorables según qué prodigia se manifestaban.

51. Montero (1994, 74) describe cómo la manifestación de un monstrum era considerada como el prodigio más grave que podría aparecer, necesitando aplacar la cólera divina de manera inmediata.

52. Cfr. Montero 1994, 74; Satterfield 2015, 431-445.

53. Cfr. Montero 1994, 73 .

54. Cic. De Div. I, 98. 
la sociedad romana ${ }^{55}$. De esta manera, este tipo de revelaciones fueron síntomas inequívocos de la ruptura de la pax deorum, siendo una forma que empleaba la divinidad para alertar de su disconformidad, pudiendo solventar esta situación a través de diferentes actos ${ }^{56}$. Las ceremonias expiatorias (procuratio prodigiorum) eran realizadas por el Senado, el cual, a través de un ritual de expiación articulaba los medios que fueran necesarios para restablecer la concordia entre las divinidades y los ciudadanos romanos ${ }^{57}$. Autores como MacBain y Montero desarrollan diversas hipótesis acerca del proceso de expiación y su significado, explicando cómo este tipo de rituales constituía una oportunidad para subrayar la identidad romana y apaciguar la colera deorum al tiempo que servía de alivio psíquico para la sociedad romana ${ }^{58}$. La lista de prodigia se presentaba al Senado cada año a principios del curso político romano a través de un informe, estos diferenciaban entre cuáles eran considerados como falsos y cuáles como verdaderos, al igual que los que habían ocurrido en el ager Romanus como en el ager peregrinus y en el ámbito privado o en el público, poniendo entonces los diferentes rituales para enmendar esa ruptura con la divinidad ${ }^{59}$. En este punto, investigadores como Dart o Montero especulan sobre la posibilidad de que los prodigios que eran registrados, tanto en Roma como en las ciudades aliadas, eran observados e incorporados en su lista por el Senado, sirviendo esto como instrumento para fomentar los lazos de alianza entre las ciudades. De igual manera, estos autores esgrimen como el reconocimiento romano de los prodigios observados en las ciudades fuera de su ámbito territorial y su expiación en la Vrbs era una forma de expresar la pertenencia de Roma con ese lugar ${ }^{60}$. Esta forma de instrumentalización de los prodigios como una forma de comunicación política entre Roma y sus aliados itálicos ha sido considerada como una forma de hacer ver la hegemonía de la Vrbs con respecto al resto, pues eran los cuerpos sacerdotales de Roma los que realizaban las correspondientes expiaciones ${ }^{61}$. Durante la Segunda Guerra Púnica se pueden observar un gran número de prodigios y consultas a los dioses, sirviendo muchas de ellas como instrumento de representación de

55. Engels 2005, 155.

56. Montero 2020, 10. Mientras que, para otros autores como Requena Jiménez (2014), el prodigio significaba el abandono de la divinidad hacia el ser humano y la situación de caos en la sociedad.

57. Montero 2020, 10-12.

58. MacBain 1982, 41; Montero 2020, 12.

59. Rasmussen 2003.

60. Dart 2012, 124; Montero 2020, 14-16.

61. MacBain 1975, 6-7. 
la crisis romana o como medio para legitimar las decisiones políticas del Senado ${ }^{62}$.

Hacia el 218 a. C. se sucedieron los primeros vaticinios sacros que utilizaron en el momento para presentar el inicio de uno de los conflictos más duros que Roma llevó a cabo ${ }^{63}$. Tito Livio ${ }^{64}$ desarrolla en su obra cómo a principios del 218 a. C. se revelaban diferentes prodigios fruto del temor religioso. Narra cómo un animal había subido solo hacia la tercera planta de un edificio y se había arrojado hacia el vacío ${ }^{65}$, cómo en el cielo se vislumbraban imágenes de navíos ${ }^{66}$ o cómo había caído un rayo en el templo de la Esperanza que se ubicaba en el foro Olitorio ${ }^{67}$. Resulta muy interesante otro de los prodigios narrados por Tito Livio para este momento, como el que un lobo se llevara la espada de uno de los centinelas que había en la Galia o cómo las tablas de la suerte de Cere se habían fragmentado $^{68}$. Al igual que los ocurridos en la Galia Cisalpina en el contexto previo de la batalla de Tesino, donde un lobo penetró en el campamento de Escipión y arrasó todo lo que pudo a su paso escapando ileso; o cómo un enjambre de abejas se posó junto a la tienda del cónsul ${ }^{69}$. Sin embargo, uno de los principales prodigios de los que la investigación se hace eco consistió en cómo un cuervo se posó sobre el cojín sagrado del templo de Juno Lanuvio ${ }^{70}$ o la caída de piedras del cielo en el Piceno ${ }^{71}$. Asimismo, tanto Livio como Dion Casio ${ }^{72}$ reconocen el primer combate en el Ródano entre la caballería de Cornelio Escipión y Aníbal como un primer presagio y augurio de cómo se iba a resolver la guerra, siendo un combate

62. Rosenberger 2005, 235-257; Montero 2020, 20. Se apunta a cerca de 148 prodigios los que fueron observados durante el transcurso del segundo conflicto romano-cartaginés.

63. No se tomará en cuenta el prodigio relacionado con un niño que volvió al útero de su madre tras el sitio de Sagunto durante el 219 a. C. (Plin. NH. 16. 79. 216) pues, aunque se considere un prodigio relacionado con el casus belli de la guerra, se desarrolló antes de la declaración formal del conflicto el fechado en el 219 a.C. durante el asedio de Sagunto

64. Liv. 21. 62. 1-4.

65. Liv. 21. 62. 3.

66. Liv. 21. 62. 4.

67. Liv. 21. 62. 4.

68. Liv. 21. 62. 5; Val. Max. 1. 6. 5; Zon. 8. 22. 5.

69. Liv. 21. 29. 4. En opinión de Engels $(2005,159)$, el prodigio relacionado con las abejas significaba la posterior herida que recibió el cónsul en la batalla de Tesino.

70. Liv. 21. 62. 4-5. En opinión de Engels (2005, 159), la ofrenda de expiación del prodigio relacionado con el templo de Juno Lanuvio iba destinada a contrarrestar un culto a una divinidad similar de los cartagineses (Tanit).

71. Tito Livio (21. 62. 5) describe estas acciones, sin embargo, Montero (1994) o Domínguez Pérez (2002) analizan estos episodios como los más característicos que sucedieron durante este año.

72. Liv. 21. 29. 4; Cass. Dio. 14.; Zon. 7. 23. 4. 
con grandes bajas, pero cuya victoria sería para el bando romano. No obstante, algunos investigadores han hipotetizado sobre la posibilidad de que este fragmento no sea considerado como prodigio en el curso de la guerra, sino un añadido por parte de estos ${ }^{73}$. El análisis que realiza Engels sobre dichos prodigios desprende cómo los avistados durante el 218 a. C. suponen un punto de inflexión en la religión romana, tanto privada como estatal, pues la excepcionalidad del conflicto hizo que se replanteasen las líneas generales de la religión y se potenciase la instrumentalización de la misma $^{74}$. Mientras que, para Montero, estos prodigios sirvieron para estrechar vínculos entre los aliados itálicos y Roma, al igual que confirmaba la unidad territorial y religiosa con los latinos, sabinos y etruscos ${ }^{75}$. Compartimos el punto de vista de ambos en cómo algunos prodigios descritos durante este año fueron empleados por los poderes públicos para calmar a la población y fortalecer las alianzas con los pueblos latinos e itálicos. Asimismo, en nuestra opinión, los prodigios narrados en las fuentes literarias pueden responder a un recurso narrativo que exponga la advertencia religiosa de cómo Roma se iba a embarcar en un conflicto contra sus antiguos enemigos, aludiendo a un paralelismo con el simbolismo de ambas civilizaciones, tanto las naves como la loba son un ejemplo de ello, como la manifestación física de los dioses en el rayo o la lluvia de piedras advirtiendo a la población de lo que se avecinaba. No obstante, la utilización de estos prodigia en el momento coetáneo sirvió para legitimar la consulta de los Libros Sibilinos y, de esta manera, calmar el temor de la gente a un conflicto armado al realizarse diferentes rituales para garantizar la pax deorum y la protección de la divinidad ${ }^{76}$.

Los diferentes prodigios aumentaron conforme la guerra avanzaba y, cuando Roma se hallaba en una situación delicada tras las derrotas en Tesino y de Trebia, se mostraban en diferentes lugares. En Sicilia, los dardos de los soldados comenzaron a $\operatorname{arder}^{77}$; en Cerdeña, el bastón de mando de uno de los jinetes también comenzó a combustionar ${ }^{78}$; en la costa italiana dos escudos habían sudado sangre, algunos legionarios habían sido alcanzados por rayos y en Prenestre comenzó a caer una lluvia de piedras ardiendo. En Arpos se había manifestado la imagen de escudos en el

73. Engels 2005, 157.

74. Engels 2005, 156.

75. Montero 2020, 16

76. Esta premisa se desprende de una de las frases de Tito Livio (21. 62. 11): «Estas expiaciones y votos conformes con los libros sibilinos aliviaron en gran medida los espíritus de escrúpulos religiosos".

77. Liv. 22. 1. 8.

78. Liv. 22. 1. 8 . 
cielo y la luna parecía combatir con el sol. Asimismo, en otras partes de la República se revelaron prodigios relacionados con los astros ${ }^{79}$. En este contexto, la narración de Celio Antipatro, recogida por Cicerón ${ }^{80}$, sobre un terremoto tras la derrota romana en el lago Trasimeno ha sido considerada por algunos investigadores como la instrumentalización de un hecho natural como un simbolismo religioso. Esta premisa fue completada por Traiana ${ }^{81}$ al afirmar cómo Celio reflejaba un momento de particular angustia religiosa y su posterior instrumentalización para calmar a la población tras la realización de diversas expiaciones religiosas. La sangre jugó otro papel fundamental en los fenómenos vinculados con la violencia de la guerra, manifestándose tanto en los agricultores de la región de Anzio como en la estatua de Marte en la vía Apia, la cual comenzó a sudarla ${ }^{82}$. A su vez, la demostración de la pugna religiosa también se exteriorizó en algunos animales, los cuales parecían haberse cambiado de sexo $^{83}$. Todos estos prodigios respondieron a la disconformidad de la divinidad con respecto a Roma, sin embargo, se desprende en las fuentes cómo el Senado consideró todos ellos para solventar la situación ${ }^{84}$. Dicha cámara los utilizó como medio para aplacar el temor de la guerra y garantizar el orden social a través de diferentes rituales, donaciones y sacrificios ${ }^{85}$. También se puede observar cómo los cónsules aprovecharon la instrumentalización de la religión del Senado para poder ejercer unas nuevas levas sin que hubiera una reticencia por parte del pueblo ${ }^{86}$.

Con el tiempo, la guerra tomó un rumbo totalmente favorable a los cartagineses tras la batalla de Cannas (216 a. C.), produciéndose diferentes ofrendas realizadas por Aníbal con el fin de vincular su causa con itálicos y griegos ${ }^{87}$. Esto se manifestó en el campo religioso con el delito de violación en las leyes de las vestales cuando mantuvieron relaciones sexuales con dos hombres. Para aplacar la ira de los dioses, se consideró castigar a las dos vestales y a sus amantes a morir, con el fin de sancionar el delito

79. En Capena aparecieron dos lunas durante el día, en Falerios se abrió el cielo como si de una grieta se tratara. En Capua había parecido que ardía el cielo y que la luna caía en medio de la lluvia.

80. Cic., div. $1,35,77$ y ss.

81. Traiana 1996, 62-65.

82. Liv. 22. 1. 10-12.

83. Liv. 22. 1. 13.

84. Liv. 22. 1. 14.

85. El desarrollo de todos los rituales y donaciones realizados para mantener la pax deorum se pueden consultar en Tito Livio (Liv. 22. 15-20).

86. Liv. 22. 2, 1.

87. Cfr. Miles 2011, 260-270; Brizzi 2014, 124-132; Barceló 2004, 69-74; 2011, 357-370; 2013, 165-170. 
religioso cometido. Engels analiza cómo esta situación, a pesar del intento de expiación de los diferentes prodigios desde que comenzó la guerra y el fracaso en las expiaciones frente a la amenaza cartaginesa, favoreció la entrada de algunos elementos helenísticos en la religión romana ${ }^{88}$. Idea que parece relacionarse con la nueva consulta en los Libros Sibilinos y cómo, de forma extraordinaria, se envió a Fabio Píctor hacia Delfos, con el fin de buscar una solución ante la situación de crisis de Roma ${ }^{89}$. Miles $^{90}$ hace una reflexión sobre cómo la búsqueda romana del Oráculo de Delfos era la única manera de restablecer la pax deorum y los lazos perdidos con la Magna Grecia tras la derrota en Cannas a manos de Aníbal y su posterior instrumentalización religiosa. A nuestro parecer, este episodio puede responder a una forma de instrumentalización político-religiosa al considerar el consejo del Oráculo de Delfos como válido y, de esa manera, mantener diversos aliados que le sirvieran durante el conflicto. De igual modo, se ha hipotetizado cómo, con motivo de la instrumentalización religiosa de Aníbal tras la invocación de la divinidad en el lago Averno (214 a. C.) para con los pueblos itálicos y griegos ${ }^{91}$, en la ciudad de Luceria se produjeron diferentes acuñaciones con tipos relacionados con el panteón romano (214-208 a. C.), a fin de intentar contrarrestar la propaganda política y religiosa que Aníbal realizaba en esta región ${ }^{92}$. También se puede constatar la aparición de otros prodigios relacionados con animales y neonatos, como fue el caso de un buey que había hablado o cómo en el vientre de una mujer un niño había exclamado "Io Triumphe»"3.

88. Engels 2005, 159.

89. Liv. 22. 57. 1, 4-6.

90. Miles 2011, 277.

91. El episodio del lago Averno en Liv. 24. 12. 4. Sobre las divinidades que participaron en dicho tratado: vid. Barré 1983. Asimismo, Barceló (2004, 74) describe cómo Aníbal supo del efecto psicológico que podía producir entre sus tropas y sus aliados si celebrara una fiesta sacra en el lago Averno y consagraba su campaña a diferentes divinidades, entre las que destacan Zeus (Bal-Eschmun), Hera (Astarté/Tanit) o Herakles (Melkart).

92. Sobre esta hipótesis véase la investigación de San Vicente (2019, 331 y ss.). Acerca de las diferentes acuñaciones que se produjeron en Luceria véase: $R R C$ 43, 1-6; 97, 1-28; 98A, 1-8; 98B, 1; 99, 1-10. Estas contienen en el anverso la efigie de una divinidad vinculada con el panteón romano (Cabeza de Roma «RRC 43/5; 97/2; 97/7a; 97/7b; 97/7c; 97/15; 97/21; 98a/3; 98a/4b; 98a/4b; 98a/7 98B; 99/8a; 99/8b», Júpiter «RRC 97/1a; 97/1b; 97/1c; 98a/1a; RRC 98a/1b; 98a/1c; 98a/1d», Dioscuros «RRC 98a/8; 98B/1" o Jano "RRC 43/1; 87/22a; 97/22b; 97/28; 99/1a; 99/1b; 99/10»), mientras que en el reverso contienen diversos tipos relacionados con la proa de un barco, los dioscuros galopando o la victoria alada coronando un trofeo o en carro.

93. Liv. 24. 10. 10. En opinión de Engels (2005, 157-158) este prodigio significaba las victorias de Aníbal en el ámbito político y militar. 
A lo largo de la guerra atendemos a un gran número de prodigios religiosos relacionados con los nacimientos de diferentes monstra ${ }^{94}$, manifestaciones físicas en los templos ${ }^{95}$ o nacimientos de niños andróginos ${ }^{96}$. No obstante, resulta interesante cómo, con el acercamiento del ejército de Aníbal a Roma, Fabio Máximo ordenó mover el templo de Hércules que se hallaba en la Porta Collina hacia el Capitolio ${ }^{97}$. Este hecho se puede relacionar con un intento de evitar que el cartaginés se relacione con su divinidad, neutralizando una posible manipulación propagandística por parte del Bárquida ${ }^{98}$. Este no fue el último ejemplo de un movimiento religioso con un claro cariz político-social. En la última etapa del conflicto, cuando se habían sucedido los últimos prodigios ${ }^{99}$ atendemos a una nueva consulta de los Libros Sibilinos y del Oráculo de Delfos en el 205-204 a. C., ambos elementos oraculares instaban a llevarse el culto de Magna Mater a Roma tras visitar al rey de Pérgamo ${ }^{100}$. Átalo llevó a los embajadores hasta Pesinunte y, allí, les regaló la piedra que simbolizaba su culto ${ }^{101}$. Para recibir el material, el Senado eligió a un hombre relacionado con la gens Cornelia que estaba relacionada con los cultos helénicos, Escipión Nasica, y a Claudia Quinta, recibiendo la piedra en la costa y trasladándola temporalmente al templo de la Victoria. En la descripción de los hechos se desarrolla cómo el barco que traía los elementos oraculares de la Magna Mater encalló en las orillas de Ostia, siendo Claudia Quinta la que sacó el barco $\mathrm{y}$, de esta forma, se pudo establecer dicho culto en Roma ${ }^{102}$. Siguiendo la narración de las fuentes literarias, Alvar analiza cómo el culto de Magna Mater permitió una suerte de reafirmación nacional al buscar un símil de una divinidad traída de Oriente, como si se refundasen los orígenes

94. Se puede mencionar la primera aparición de un monstrum con cabeza de elefante durante el 209 a. C. (Liv. 27. 11. 5).

95. Se hace mención a la caída de un rayo en el templo de Juno Sóspita en Lavinio durante el 215 a. C. (Liv. 23. 31. 15).

96. Durante el 209 a. C. en Sinuessa (Pol. 3. 12; Liv. 27. 11. 4).

97. Plin. NH, 34. 40.

98. Miles 2011, 277.

99. La caída de un rayo en el templo de Juno Regina y nacimiento de un andrógino en el 207 a. C.

100. Liv. 29. 11. 5-6.

101. En referencia a la "piedra negra» y su entronización en Roma véase en Sil It. 17. 1-47; Cic. Cael. 34; V. Máx. 7. 5. 2. y 8, 15, 3. Vid. Albrecht 1968, 76-95; Gérard 1980, 153-175.

102. Liv. 29. 11. 5-6. Dicha narración de cómo el culto se llevó a Roma tiene grandes similitudes con la historia de Pausanias y el barco que transportaba una estatua de Hércules de estilo egipcio que encalló en Erythrae y cómo la participación femenina y la intervención divina pudieron salvar la embarcación (Burns 2017, 88-89). 
míticos de la ciudad de Roma con Eneas ${ }^{103}$; mientras que Burns explica cómo el milagro de Claudia y el rescate del barco permitió establecer una posición de importancia religiosa en la sociedad romana y cómo, gracias a esto, se pudo salvar la República tras unificar un culto foráneo con las tradiciones romanas ${ }^{104}$. Autores como Cid López ${ }^{105}$ o Miles $^{106}$ reflexionan sobre este acontecimiento y cómo este hecho fue fruto de una instrumentalización religiosa con el fin de asestar un golpe propagandístico a los cartagineses y, de esta manera, volver a unir a griegos y romanos bajo el culto de Magna Mater, mermando la alianza entre helenos y cartagineses que se había fortalecido desde el 215 a. C. De igual modo, se observa cómo la elección de Claudia Quinta como parte de la comitiva para recibir los elementos oraculares de la Magna Mater no fue casual y tuvo mucha problemática en el mismo momento. La designación de esta mujer ha sido muy tratada por diversos autores, algunos describen la dudosa honorabilidad a la hora de su designación y de las dudas que provocaba en la sociedad romana ${ }^{107}$, mientras que otros dudan sobre la existencia real de esta en el contexto que se realizó el ritual de acogida del culto a la Magna Mater $^{108}$.

\section{LA MANIPULACIÓN DE LA RELIGIÓN EN EL ÁMBITO MILITAR ROMANO}

De la misma manera que la religión sirvió como trampolín para la legitimación político-social y su instrumentalización para validar las acciones que realizaban tanto los privados como el Senado, el ámbito militar no fue una excepción. A pesar de lo ocurrido con Fabio Máximo o Minucio Rufo, los cuales no la utilizaron en este campo sino en el político, en el ejército asistimos a su empleo como un medio por el cual infundir valor, motivar o legitimar una acción. No solamente se pueden observar estos ejemplos

103. Alvar 1994, 154.

104. Burns 2017, 92-93.

105. Cid López 2007, 24.

106. Miles 2011, 278.

107. Sobre la elección de esta mujer, Gérard (2001, 159-168) analiza el complejo proceso de su elección, debido a que Claudia Quinta tuvo una reputación dudosa que no pudo ser superada hasta época augustea, donde se convirtió en modelo de castidad bajo la protección de Magna Mater. De igual modo, Cid López (2007, 24) hace una reflexión acerca de la prueba de honorabilidad que realizó al recibir los símbolos oraculares de la divinidad.

108. Varios investigadores como Alvar (1994, 160-162), Scheid (2001, 23-31), Winsor Leach (2007, 1-9) o Burns (2017, 82-90) desarrollan cómo las fuentes literarias posteriores varían de versión a conveniencia de los intereses políticos del momento, por lo que la existencia, o no, de Claudia Quinta y la posibilidad de que fuera una vestal en vez de una matrona. 
en la Península Itálica, sino la manipulación de las instituciones religiosas indígenas en el ámbito militar en el caso hispano.

El primer caso de estudio en el que se vislumbra la adulteración religiosa en este campo se puede observar durante el asedio a Qart Hadasht (Cartagena) en el año 209 a. C. El estudiado caso de la laguna de Cartagena durante la toma "escipiónica" de la ciudad cartaginesa ha tenido muchos matices a nivel militar o arqueológico ${ }^{109}$, sin embargo, en el ámbito religioso se tiene constancia de la utilización de la vinculación divina de Escipión con la decisión de tomar la ciudad por un lado «infranqueable». Su instrumentalización del empleo táctico para entrar en la urbe radica en la propia afinidad entre la divinidad y la persona que divulgaba ser. Polibio ${ }^{110}$ nos describe cómo difundió entre sus hombres que Neptuno le había hablado en sueños para comunicarle que le apoyaba en su empeño por tomar la ciudad púnica y que le bajaría las aguas de una zona de la muralla para que pudieran subir por los muros. Tito Livio ${ }^{111}$, al igual que Polibio, mantiene la narración de cómo Escipión utilizó el movimiento natural de las aguas para atribuirlo a una intervención divina que contribuiría a su asedio. No obstante, ambos autores explican cómo el general aprovechó el reflujo natural de la laguna como si de una mediación de los dioses le ayudaría en su causa ${ }^{112}$. En la investigación actual no existe un debate sobre el ámbito religioso de este hecho, sino la capacidad de recogida de información y los lugares de donde la obtuvo ${ }^{113}$. Por tanto, asistimos a la instrumentalización sacra consciente de una masa de legionarios para infundirles valor y legitimar una decisión táctica que sabía, por la información obtenida, que iba a suceder.

Al poco tiempo se sucedió la adulteración de los augurios para conocer si los dioses eran propicios para entablar combate ${ }^{114}$. Durante el año

109. Algunas investigaciones hacen eco de la realidad arqueológica de la ciudad en la época de Escipión, de sus murallas de casamatas, la altura o el sistema defensivo que se ha descubierto. (Cfr. Lechuga 1993, 159-160; Bendala Galán y Blánquez 2002-2003, 145-160; Antolinos 2003, 119-124; Noguera et al. 2012-2013, 35-74; Blánquez 2013, 209-253; Noguera Celdrán 2013, 143-152; Noguera Celdrán y Madrid Balanza 2014, 17 y ss.; Ramallo y Martín 2015; Bendala Galán 2015; Ramallo y Ros Sala 2016, 168 y ss.).

110. Plb. 10. 11, 6-8.

111. Liv. 26. 45, 8-9.

112. El propio Polibio $(10.8,7-8)$ describe cómo se enteró de la geografía y de este fenómeno marítimo gracias a la información de unos pescadores mientras realizaba los preparativos en Tarraco.

113. Vid. Fernández Rodríguez 2005, 62-69.

114. Existen ejemplos de la manipulación de los augurios antes de salir al combate para proyectar en sus legionarios que la protección de la divinidad les acompañaba, como el caso de Publio Claudio Pulcro durante la Primera Guerra Púnica (Plb. 1. 49-51; V. Máx. 1, 4). 
208 a. C., Claudio Marcelo realizó un sacrificio en el que, a través de los resultados que habría obtenido, saldría al encuentro de Aníbal Barca. No obstante, el primero de ellos resultó nefasto, debido a que se había presentado el hígado sin la parte de la cabeza, por lo que se realizó un segundo para confirmar el resultado anterior, siendo favorable en esta ocasión. Sin embargo, la manipulación del sacrificio para que saliera favorable resultó en su derrota y su asesinato ${ }^{115}$. Este tipo de adulteración religiosa, con un resultado negativo por parte del general, era habitual en algunas batallas, aunque las fuentes destacan las ocasiones ejemplares en donde los augurios son condicionados para que fueran favorables a la decisión del mando en cuestión. Este tipo de instrumentalización tuvo la función de infundir el ánimo entre la tropa y mantener la pax deorum con las acciones bélicas, pues la sanción favorable de la divinidad acompañaba a la estrategia del mando. De manera similar, en Hispania, antes de la batalla de Ilipa, Escipión realizó diversos sacrificios para conocer el destino del combate, sacando las vísceras de un animal y, ante esto, unas aves se aproximaron en señal de victoria ${ }^{116}$. Sin embargo, la interpretación del texto de Apiano ha sido discutida por algunos investigadores, Montero describe cómo, al hilo del discurso de las inspiraciones divinas, el general romano se sirvió del olor de las vísceras para atraer a las aves y, de esta manera, instrumentalizar un sacrificio para acrecentar la moral de la tropa antes de la batalla ${ }^{117}$. Dentro de los diversos prodigios que se relacionan con Escipión Africano, nos parece curioso comentar cómo, durante la preparación de la invasión en África (204 a. C.), una serpiente se deslizó por el camino que conduce a Cartago ${ }^{118}$, sirviendo de paralelismo a lo ocurrido años antes con Marco Atilio Régulo o con un episodio similar del sueño de Aníbal en las orillas del Ebro ${ }^{119}$.

En Hispania se dieron otros casos documentados de la instrumentalización religiosa, no obstante, en esta ocasión, no fue dirigida hacia sus propias tropas, sino hacia los propios indígenas con la adulteración de la fides y la devotio ${ }^{120}$ ibéricas, instituciones de carácter

115. Liv. 27. 26. 13-14; V. Máx. 1. 6. 9.

116. Ap. $I b .26$.

117. Montero 2020, 114-115.

118. Cass. Dio. 17. 63.

119. Engels 2007, 485; Montero 2020, 120-122.

120. La devotio es una de las instituciones religiosas que mayor vinculación tuvo con el mundo romano durante la Segunda Guerra Púnica (Ramos y Locertales 1924, 7; Prieto 1978, 133; Curchin 1991; Fishwick 1996, 184). Al igual que esta institución, la fides o el hispicium eran variables y evolucionaban según la dinámica del momento, Roma tuvo la 
religioso ${ }^{121}$. Los lazos de fidelidad que se creaban a través de este medio estaban relacionados con la unión clientelar de un líder ibérico o un grupo con un jefe militar fuerte que, con frecuencia, solía ser extranjero ${ }^{122}$. Las obligaciones de los que ejercían la devotio en la figura extranjera fueron comúnmente la lucha por la persona en la que depositaban el culto hasta el punto de poner sus vidas al servicio de este, llegando a suicidarse en caso de que la persona con la que se realizaba moría ${ }^{123}$. Cuando se tomó la ciudad de Qart Hadasht, los reyezuelos ilergetes Indíbil y Mandonio pusieron sus vidas bajo la protección de Escipión. Sin embargo, se observa la devotio tras el episodio de sublevación por parte de los iberos, donde Indíbil y Mandonio se acogían a las decisiones de Escipión como depositario de su devotio ${ }^{124}$. Observamos cómo Escipión, al igual que hicieran los Bárquida, se aprovechó de esta vinculación para manipular a los cabecillas de estos grupos y, de esta manera, controlar a los grupos que estos lideraban ${ }^{125}$.

\section{CONClusiones}

El periodo de la Segunda Guerra Púnica fue una etapa donde se han podido observar un gran número de acciones relacionadas con la instrumentalización de la religión, desde el ámbito interno de la ciudad, el militar o las relaciones diplomáticas entre civilizaciones. Asimismo, se puede observar un incremento de prodigios religiosos o de la utilización de mecanismos de manipulación religiosa durante los momentos de mayor crisis en la ciudad, como, por ejemplo, tras las derrotas en el Tesino, en Trebia, en el lago Trasimeno, la batalla de Cannas o tras la llegada de Aníbal a las puertas de Roma en el contexto de la toma de Capua. Las

oportunidad de aprovecharse de ellos y vincular los grandes líderes militares ibéricos con generales extranjeros (Prieto 1978, 133).

121. En Roma existió una institución llamada devotio en la cual un magistrado que tuviera el cum imperio consagraba su vida a los dioses infernales para eliminar a un enemigo, sacrificando su vida por el bien de Roma en un conflicto (Versnel 1976: 365 y s.).

122. Prieto $1978,133$.

123. Alarcón 2013, 211.

124. Tito Livio (28. 34. 5) describe la situación de la siguiente manera: «O bien le devolvían a Escipión, si lo deseaba, la vida que de él habían recibido, o bien, si les perdonaba, le dedicaban para siempre la vida que le debían dos veces sólo a él».

125. Étienne $(1958,75-78)$ analiza cómo este tipo de vinculación religiosa entre los líderes ibéricos y los cabezas de ejércitos extranjeros comenzó a ser habitual durante el Imperialismo Bárquida y, adaptando las mismas formas que hubieran realizado los cartagineses, los generales de la república romana. 
instituciones romanas, como el Senado, supieron aprovecharse de la piedad religiosa generalizada entre su población para, a través de diferentes sanciones, intentar calmarla e introducir cambios en los cultos para intentar atraer a los diferentes aliados que habían cambiado su postura diplomática para con la Vrbs e intentar neutralizar el entramado propagandístico religioso de los cartagineses. No obstante, a pesar de existir una instrumentalización de los procesos religiosos a través de las instituciones del gobierno de la República, se observa cómo, a propósito de ello, diversas personalidades legitimaron su campaña política o sus actos en combate gracias a la «intervención" de los dioses marcándoles como sus elegidos, tales como el caso de Minucio Rufo o Cornelio Escipión. Por último, se puede observar cómo las fuentes literarias intentan legitimar algunas actitudes de Roma a través de la búsqueda de la pax deorum, empleando este recurso como una forma de exculpar las malas decisiones del Senado o de las diversas personalidades.

\section{Bibliografía}

Alarcón Hernández, Carmen. "La devotio ibérica y R. Étienne: ¿El origen del culto imperial en Hispania?». ARYS 11 (2013): 209-226.

Albrecht, Michael von. "Claudia Quinta bei Silius Italicus und bei Ovid". Der Altsprachliche Unterricht: Latein, Griechisch XI (1) (1968): 76-95.

Almagro Gorbea, Martín. «Los relieves mitológicos orientalizantes de Pozo Morom. Trabajos de Prehistoria 35 (1978): 251-278.

Almagro Gorbea, Martín. «Iconografía fenicia y mitología tartésica. El influjo fenicio de las creencias de Tartessos». En Studi Iconografici nel Mediterraneo antico. Iconologia ed aspetti materici, editado por E. Acquaro, 11-64. La Spezia, 2004.

Alvar, Jaime. «Escenografía para una recepción divina: la introducción de Cibeles en Roma». DHA 20.1 (1994): 149-169.

Anderson, Andrew Runni. «Heracles and his successors. A study of a heroic ideal and the recurrence of a heroic type». Harvard Studies in Classical Philology XXXIX (1928): 7-58.

Antolinos Marín, Juan Antonio. «Técnicas edilicias y materiales de construcción en el cerro del Molinete (arx Asdrubalis, Carthago Nova». En Arx Asdrubalis. Arqueología e Historia del Cerro del Molinete (Cartagena), I, coordinado por J. M. Noguera Celdrán, 115-160. Murcia, 2003.

Aymard, Jacques M. «Scipion l'Africain et les chiens du Capitole». Revue des Études Latines XXXI (1953): 111-116. 
Barceló Batiste, Pedro. «Die ideologische Kriegführung Hannibals». En Studi in onore di Michele R. Cataudella, editado por S. Bianchetti, 63-80. La Spezia: Agorà Edizioni, 2001.

Barceló Batiste, Pedro. "Los dioses de Aníbal». En El mundo púnico: religión, antropología y cultura material: actas II Congreso Internacional del Mundo Púnico, coordinado por G. Matilla Séiquer, A. Egea Vivancos y A. González Blanco, 69-76. Cartagena, 2004.

Barceló Batiste, Pedro. Aníbal: Estratega y estadista. Madrid: La Esfera de los Libros, 2010.

Barceló Batiste, Pedro. "Punic Politics, Economy, and Alliances, 218-201". En A Companion to the Punic Wars, coordinado por D. Hoyos, $357-$ 375. Oxford: Wiley Blackwell, 2011.

Barceló Batiste, Pedro. "Aníbal y la helenización de la guerra en Occidente». En Aníbal de Cartago. Historia y mito, editado por S. Remedios, F. Prados y J. Bermejo, 159-175. Madrid, 2012.

Barceló Batiste, Pedro. «Sobre la utilización de la religión en la II Guerra Púnica». ARYS 11 (2013): 163-172.

Barré, Michael L. The God-List in the Treaty between Hannibal and Philip $V$ of Macedonia. A Study in Light of the Ancient Near Eastern Treaty Tradition. Baltimore: The Johns Hopkins University Press, 1983.

Bendala Galán, Manuel. «Die orientalische religionen hispaniens in corrömischer und römiscer Zeit». ANRW 11/18 (1986): 380-393.

Bendala Galán, Manuel. «El privilegio histórico y cultural de la moneda: aliento y compromiso científico». En Actas XIII Congreso Nacional de Numismática: Moneda y Arqueología, coordinado por A. Arévalo González, 17-48. Cádiz, 2008.

Bendala Galán, Manuel. "Aníbal y los Barca: el proyecto político cartaginés de Hispania». En Fragor Hanibalis. Aníbal en Hispania, coordinado por M. Bendala Galán, 46-81. Madrid, 2013.

Bendala Galán, Manuel. Hijos del Rayo: Los Barca y el dominio cartaginés en Hispania. Madrid: Trébede, 2015.

Bendala Galán, Manuel y Juan Blánquez. «Arquitectura militar púnico-helenística en Hispania». En Forma e imágenes del poder en los siglos III y II a. d. C.: modelos helenísticos y respuestas indigenas, coordinado por F. Quesada Sanz, M. Bendala Galán y P. Moret, 145-160. Madrid, 20022003.

Blánquez, Juan. "Arquitectura y poder: las fortalezas bárquidas en Hispania». En Fragor Hanibalis. Aníbal en Hispania, coordinado por M. Bendala Galán, 209-253. Madrid, 2013.

Blázquez, José María. "Las raíces clásicas de la cultura ibérica. Estado de la cuestión. Últimas aportaciones». AEA 52 (1979): 141-174. 
Blázquez, José María. Primitivas religiones ibéricas. Religiones prerromanas II. Madrid: Ediciones Cristiandad, 1983.

Blázquez, José María. «El influjo de la cultura semita (fenicios y cartagineses) en la formación de la cultura ibérica». Aula. Or. 4 (1986): 163-178.

Blázquez, José María. "La religión de los pueblos de la Hispania Prerromana». Zephyrus 43 (1990): 223-233.

Blázquez, José María. «La religión tartésica y fenicia del periodo orientalizante». En Historia de las religiones de la Europa Antigua, coordinada por J. M. Blázquez,159-194. Madrid, 1994.

Blázquez, José María y María de la Paz García-Gelabert. «El impacto fenicio en la religiosidad indígena». En Actas del IV Congreso Internacional de Estudios Fenicios y Púnicos, coordinado por M. Barthélemy y M. E. Aubet Semmler, 551-549. Cádiz, 2000.

Bloch, Raymond. Los prodigios en la antigüedad clásica. Buenos Aires: Paidós, 1968.

Bloch, Raymond. "Hannibal et les dieux de Rome». Comptes Rendus / Académie des Inscriptions et Belles-Lettres 119-1 (1975): 14-25.

Breccia, Gastone. Scipione l'Africano. L'invincibile che rese grande Roma. Roma: Salerno Editrice, 2017.

Breglia Pulci Doria, Luisa. Oracoli Sibillini tra rituali e propaganda (Studi su Flegonte di Tralles). Nápoles: Ligouri Editori, (1983).

Brizzi, Giovanni. Annibale. Bologna: Il Mulino, 2014.

Buono-Core Varas, Raúl. "Los tratados en el mundo romano». Revista de Estudios Histórico Jurídicos 25 (2003): 23-24.

Burns, Krishni. "Constructing a new woman for the body politic: the creation of Claudia Quinta». Helios: A Journal Devoted to Critical and Methodological Studies of Classical Culture, Literature and Society 44 (1) (2017): 81-98.

Cabrero Piquero, Javier. Escipión El Africano. La forja de un imperio universal. Madrid: Aldebarán, 2000.

Campus, Alessandro. «Annibale e Scipione : Riflessioni storico-religiose sulla seconda guerra punica». Rendiconti della Accademia dei Lincei 21 (2008): 121-182.

Chaves Tristán, Francisca y María Cruz Marín Ceballos. «L'influence phénico-punique sur l'iconographie des frappes locales de la Péninsule ibérique». En Studia Phoenicia IX. Numismatique et histoire economique phenicienne et punique, editado por T. Hackens y M. Ghislaine, 167194. Lovain-La. Neuve, 1992.

Cid López, Rosa María. "Las matronas y los prodigios. Prácticas religiosas femeninas en los «márgenes» de la religión romana». Norba. Revista de Historia 20 (2007): 11-29. 
Curchin, Leonard A. "Cult and Celt: indigenous participation in emperor worship in central Spain". Journal of Roman Archaeology 17 (1996): 143-152.

Dart, Christopher J. «The Address of Italian Portents by Rome and the Ager Publicus". L'Antiquité Classique 81 (2012): 111-124.

Díaz Sánchez, Carlos. «El mecenazgo como mecanismo de legitimación política durante la II Guerra Púnica. El caso de Minucio Rufo (217 a.C)». En Coleccionismo, mecenazgo y mercado artístico: Orbis Terrarum coordinado por A. Holguera Cabrera, E. Prieto Ustio y M. Uriondo Lozano, 105-113. Sevilla, 2020.

Domínguez Monedero, Adolfo Jerónimo. «Hellenisation in Iberia? The reception of Greek products and influences by the Iberians». En Ancient Greeks, West and East, editado por G. R. Tsetskhladze, 301329. Leiden, 1999.

Domínguez Pérez, J. C. «Dimensión económico-política de la estructura ideológica en el nuevo estado romano republicano anterior a la guerra de Aníbal». SPAL: Revista de Prehistoria y Arqueología de la Universidad de Sevilla 11 (2002): 297-310.

Dumézil, Georges. «Remarques sur le ius fetiale». REL 34 (1956): 93-108.

Dumézil, Georges. La religion romaine archaïque. Paris: Payot, 1966.

Engels, David. "Eo anno multa prodigia facta sunt: das Jahr 218 als Wendepunkt des römischen Vorzeichenwesens». En Mantik: Profile prognostischen Wissens in Wissenschaft und Kultur, editado por W. Hogrebe, 151-166. Königshausen und Neumann, 2005.

Engels, David. Das romische Vorzeichenwesen (753-27 v. Chr.). Queden, Terminologie, Kommentar, historische Entwicklung (Potsdamer Altertumswissenschaftliche Beiträge 22). Stuttgart: Franz Steiner, 2007.

Erskine, Andrew. "Hannibal and the freedom of the Italians". Hermes: Zeitschrift für Klassische Philologie 121 (1) (1993): 58-62.

Etienne, Robert. Le culte impérial dans la péninsule ibérique. Paris: E. De Boccard, 1958.

Fernández Rodríguez, David. «La toma de Carthago Nova por Publio Cornelio Escipión: ¿Leyenda o Realidad». Polis. Revista de Ideas y Formas Políticas de la Antigüedad Clásica 17 (2005): 31-72.

Fishwick, Duncan. "Four temples at Tarraco». En Subject and Ruler: The Cult of the Ruling Power in Classical Antiquity, editado por A. Small, 165-184. Ann Arbor, 1996.

Fronda, Michael P. "Hegemony and rivalry: the revolt of Capua revisited». Phoenix 61 (2007): 83-108. 
Galindo Roldán, Juan Manuel. "Los tratados y la diplomacia en la antigüedad: el derecho internacional como sistema de la conquista romana». Lecciones y Ensayos 91 (2013): 201-208.

Galinsky, Karl. Aeneas, Sicily, and Rome. Princeton: Princeton Legacy Library, 1969.

García Cardiel, Jorge (2013): «De la hierogamia a la ofrenda. El contacto con la divinidad en el mundo ibérico", Mediterraneo Antico XVI (I), pp. 277-308.

García-Bellido, María de la Paz. «Estuvo Àkra Leuké en Carmona?». Paleohispánica. Revista sobre Lenguas y Culturas de la Hispania Antigua 10 (2010): 201-218.

García-Bellido, María de la Paz. «El nacimiento del retrato monetario en Occidente: La familia Bárquida». En Fragor Hanibalis. Aníbal en Hispania, coordinado por M. Bendala Galán, 174-207. Madrid, 2013.

García-Gelabert Pérez, María de la Paz. «La religión ibérica a través de las necrópolis». Zephyrus 43 (1990): 259-266.

Gérard, Hunen van. "Légende et politique autour de la Mère des dieux". Revue des Études Latines LVIII (1980): 153-175.

González Wagner, Carlos. «Los Bárquidas y la conquista de la Península Ibérica». Gerión 17 (1999): 263-294.

González Wagner, Carlos. «El sufetato de Aníbal». En Aníbal de Cartago. Historia y mito, editado por S. Remedios, F. Prados y J. Bermejo, 251276. Madrid, 2012.

Greenland, Fiona. «Devoto ibérica and the manipulation of ancient history to suit Spain's mythic nationalist past». Greece \& Rome 53 (2) (2006): 235-251.

Gruen, Erich S. Culture and National Identity in Republican Rome. New York: Cornell University Press, 1992.

Harris, William V. Guerra e imperialismo en la Roma republicana, 327-20 a.C. Madrid: Siglo XXI, 1989.

Hoyos, Dexter. "Carthage in Africa and Spain, 241-218». En A Companion to the Punic Wars, coordinado por D. Hoyos, 204-222. Oxford: Wiley Blackwell, 2011.

Huss, W. "Hannibal und die Religion». En Studia Phoenicia 4. Religio Phoenicia, editado por E. Lipinski, C. Bonnet y P. Marchetti, 223-238. Lovaina, 1986.

Jiménez Rojas, Juan Pablo. "Guerra preventiva y bellum iustum en la República Romana: III-I a.C.». Revista Historia UdeC 20 (2) (2013): 43-54.

Kakarieka, Julius. "Los orígenes de la doctrina de la Guerra Justa. Cicerón y la tradición romana». Cuadernos de Historia 1 (1981): 7-29. 
LA RELIGIÓN COMO INSTRUMENTO DE MANIPULACIÓN POLÍTICO-MILITAR EN ROMA..

Knapp, Robert C. «La vía Heraclea en el Occidente; mito, arqueología, propaganda, historia». Emérita: Revista de Lingüistica y Filología Clásica LIV (1986): 103-122.

Lechuga Galindo, Manuel. «La presencia púnica en Cartagena. Testimonios numismáticos». Acta Numismática 21-23 (1993): 155-165.

López Barja de Quiroga, Pedro Manuel. «Sobre la guerra justa». SEMATA Ciencias Socials e Humanidades 23 (2011): 61-75.

López Castro, José Luis. "Familia, poder y culto a Melqart Gaditano". ARYS 1 (1998): 93-108.

López Monteagudo, Guadalupe y María del Pilar San Nicolás Pedraz. "Astarté-Europa en la Península Ibérica. Un ejemplo de interpretatio romana». Complutum Extra 6 (1) (1996): 451-470.

MacBain, Bruce. The function of public prodigies and their expiations in furthering the aims of Roman Imperialism in Italy down to the period of the social war. Boston University, 1975. [Tesis doctoral].

MacBain, Bruce. Prodigy and expiation: a study in religion and politics in Republican Rome (Latomus vol. 177). Bruselas, 1982.

Madrid, Raúl. "El concepto de "guerra justa» en la relación con la unidad de los pueblos europeos». Verbo 305-306 (1992): 641-650.

Mangas, Julio. "Conventus deorum y dei consentes». Gerión 12 (1994): 279-286.

Martínez-Pinna, Jorge. "Diodoro Sículo y los reyes de Roma», Gerión 29 (1) (2011): 107-121.

Miles, Richard. "Hannibal and propaganda". En A Companion to the Punic Wars, coordinado por D. Hoyos, 260-279. Oxford: Wiley Blackwell, 2011.

Mira Guardiola, Miguel Ángel. Cartago contra Roma. Las guerras púnicas. Cuenca: Aldebarán, 2008.

Montero, Santiago. Diosas y adivinas. Mujer y la adivinación en la Roma Antigua. Madrid: Trotta, 1994.

Montero, Santiago. Prodigios en la Hispania Romana. Rayos, terremotos, epidemias y eclipses. Madrid: Guillermo Escolar, 2020.

Noguera Celdrán, José Miguel. "Qart Hadast, capital bárquida de Iberia». En Fragor Hanibalis. Aníbal en Hispania, coordinado por M. Bendala Galán, 135-173. Madrid, 2013.

Noguera Celdrán, José Miguel y María José Madrid Balanza. «Carthago Nova: Fases e hitos de monumentalización urbana y arquitectónica (siglos III a.C.-III d.C.)». Espacio, Tiempo y Forma. Serie I: Prehistoria y Arqueología 7 (2014): 13-60.

Oost, Stewar Irving. "The fetial law and the outbreak of the Juguthine War». The American Journal of Philology vol. 75 (2) (1954): 147-159. 
Plácido, Domingo. Poder y Discurso en la Antiguedad Clásica. Madrid: Abada Editores, 2008.

Prieto Arciniega, Alberto. «La devotio ibérica como forma de dependencia en la Hispania Prerromana». Memorias de Historia Antigua 2 (1978): 131-135.

Quesada Sanz, Fernando. "Aníbal Barca y Publio Cornelio Escipión el Africano: vidas divergentes, muertes paralelas». En Enemistades peligrosas, editado por F. García Romero y A. Moreno Hernández, 175207. Madrid, 2013.

Quesada Sanz, Fernando. "Los Escipiones, generales de Roma». En Los Escipiones. Roma conquista Hispania, coordinado por M. Bendala Galán, 67-90. Madrid, 2016.

Ramallo Asensio, Sebastián F. y María de la Milagrosa Ros Sala. «De Qart Hadast a Carthago Nova: la conquista de Escipión como transfondo». En Los Escipiones. Roma conquista Hispania, coordinado por M. Bendala Galán, 163-179. Madrid, 2016.

Ramallo Asensio, Sebastián F. y Miguel Martín Camino. «Qart-Hadast en el marco de la Segunda Guerra Púnica». En La Segunda Guerra Púnica en la Península Ibérica. Baecula, Arqueología de una batalla, editado por J. P. Bellón, A. Ruiz, M. Molinos, C. Rueda y F. Gómez, 129-162, 2015.

Ramos y Loscertales, José María. "La "devotio» ibérica». Anuario de Historia del Derecho Español 1 (1924): 7-26.

Rasmussen, Susanne William. Public portents in republican Rome. Roma: L'Erma di Bretschneider, 2003.

Requena Jiménez, Miguel. Omina Mortis. Presagios de muerte. Cuando los dioses abandonan al emperador romano. Madrid: Abada Editores, 2014.

Rich, John. "The fetiales and roman international relations". En Priest and State in the Roman World, editado por J. H. Richardson y F. Santangelo, 187-242. Stuttgart, 2011.

Richardson, James H. «The development of the treaty-making rituals of the Romans». Hermes: Zeitschrift für Klassische Philologie 145 (3) (2017): 250-274.

Riesco Álvarez, Hipólito-Benjamín. «Iuppiter Lapis» y el "Lapis Silex». Estudios Humanísticos Filología, 10 (1988): 19-28.

Rodríguez Neila, Juan Francisco. «Liberalidades públicas y vida municipal en la Hispania Romana». Veleia 6 (1989): 135-170.

Rosenberger, Veit. "Prodigien aus Italien: geographische Verteilung und religiöse Kommunikation". Cabiers du Centre Gustave Glotz 16 (2005): 235-257.

San José Campos, Christian. "La Imitatio Alexandri de Aníbal Barca». SHHA 38 (2020): 21-48. 
San Vicente, José Ignacio. "La diosa Ceres en la moneda romana republicana». En Hispania et Roma: Estudios en homenaje al profesor Narciso Santos Yanguas, coordinado por J. I. San Vicente, C. Cortés y E. González, 231-248. Oviedo, 2019.

Santangelo, Federico. "The fetials and their ius». BICS 51 (2008): 63-93.

Santos Velasco, Juan Antonio. "Análisis sobre la transición a una sociedad estatal en la cuenca media del Segura en época ibérica (s. VI-III a.C.)». Trabajos de Prebistoria 46 (1989): 129-147.

Satterfield, Susan "Prodigies, the "pax deum» and the "ira deum». The Classical Journal 110 (4) (2015): 431-445.

Scheid, John. "Claudia the vestal virgin". En Roman women, editado por A. Fraschetti y L. Lappin, 23-33. University of Chicago Press, 2001.

Schilling, Robert. La religion romaine de Vénus, depuis les origines jusqu'au temps d'Auguste. Paris: E. de Boccard, 1954.

Schullard, Howard Hayes. "Rome's declaration of war on Carthage in 218 b.C.». Rheinisches Museum für Philologie, Neue Folge 95(3) (1952): 209-216.

Schultz, Celia E. Women's Religious Activity in the Roman. Republic. Chapel Hill: University of North Carolina Press, 2006.

Sgarbi, Romano. "A propósito del lessema latino "fētiālēs" ", Aevum 66 (1992): 71-78.

Smith, Roland Ralph Redfern. Hellenistic Royal Portraits. Oxford: Clarendon Press, 1986.

Steinby, Christine. Rome versus Carthage. The War at Sea. Yorkshire: Pen \& Sword, 2015.

Stepper, Ruth. "Politische Parolen und Propaganda im Hannibalkrieg». Klio: Beiträge zur Alten Geschichte 88 (2) (2006): 397-407.

Traina, Giusto. "Celio Antipatro e il terremoto del 217 a.C.: (fr. 20 Peter)». Eutopia: Commentarii Noui de Antiquitatibus Totius Europae 5(1-2) (1996): 59-65.

Versnel, Henk S. "Two types of Roman devotio». Mnemosyne 29 (1976): 350-410.

Villaronga, Leandro. Las Monedas Hispano-Cartaginesas. Barcelona: Sección Numismática del Círculo Filatélico y Numismático, 1973.

Walbank, Frank William. "Roman declaration of war in the Third and second centuries». Classical Philology vol. 44 (1) (1949): 15-19.

Walbank, Frank William. "The Scipionic legend". Proceedings of the Cambridge Philological Society XIII (1967): 54-69.

Wiedemann, Thomas. "The Fetiales: A reconsideration". Classical Quarterly 36 (II) (1986): 478-490.

Winsor Leach, Eleanor. "Claudia Quinta (Pro Caelio 34) and an altar to Magna Mater». Dictynna: Revue de Poétique Latine 4 (2007): 1-16. 